\title{
Cell wall structure of selected yeast species as a factor of magnesium binding ability
}

\author{
A. Bzducha-Wróbel • St. Błażejak $\cdot$ K. Tkacz
}

Received: 28 March 2012/Revised: 16 May 2012/ Accepted: 19 May 2012/Published online: 17 June 2012

(C) The Author(s) 2012. This article is published with open access at Springerlink.com

\begin{abstract}
This study was undertaken to determine the magnesium ion biosorption ability of the C. utilis and $S$. cerevisiae yeast species during cultivation in model media supplemented with magnesium. The mannoprotein and $\beta$-glucan content in the investigated yeast cell wall were analyzed because of the essential function of yeast cell wall structural components in metal ion binding. At the same time, an observation of yeast cells with the use of a transmission electron microscopy (TEM) was performed. The $S$. cerevisiae No. 1 yeast demonstrated the largest magnesium cation biosorption capacity. The magnesium content in biomass of $S$. cerevisiae No. 1 was about $16 \mathrm{mg} \mathrm{Mg}{ }^{2+} / \mathrm{g}$ of dry substance after living cell incubation in $\mathrm{MgSO}_{4}$ solution and about $18 \mathrm{mg} \mathrm{Mg} \mathrm{Mg}^{2+} / \mathrm{g}$ of dry substance after pasteurized biomass incubation in YPD medium supplemented with magnesium ions. The tested yeast strains differed in mannoprotein and $\beta$-glucan content in the cell wall. The cell wall of $S$. cerevisiae 102, coming from YPD $+\mathrm{Mg}^{2+}$ medium, contained the greatest amount of glycoproteins (approx. $66 \%$ adjusted to a total sugar basis). The cell wall of $C$. utilis ATTC 9950 yeast incubated under the same conditions was composed mainly of $\beta$-glucans (approx. $78 \%$ ) with prevailing $\beta$-(1,6)-glucans in this glucose polymer fraction (approx. $53 \%$ ). In S. cerevisiae No. 1 and C. utilis yeasts, higher degrees of magnesium ion binding were observed in the presence of higher $\beta$-glucan content in the cell wall structure, whereas in $S$. cerevisiae, 102 cells the magnesium ion adsorption was determined mainly on the grounds of mannoprotein
\end{abstract}

A. Bzducha-Wróbel $(\bowtie) \cdot$ St. Błażejak · K. Tkacz Faculty of Food Sciences, Department of Biotechnology, Microbiology and Food Evaluation, Warsaw University of Life Sciences, ul. Nowoursynowska 159c, Warszawa, Poland e-mail: anna_bzducha_wrobel@sggw.pl presence. The process of yeast cell pasteurization increased the magnesium ion binding ability in the tested fungi strains as a result of cell wall structure loosening.

Keywords Yeast cell wall · Candida utilis . Saccharomyces cerevisiae · Magnesium binding

$\begin{array}{ll}\text { Abbreviations } & \\ \text { ASA } & \text { Atomic absorption spectrometry } \\ \text { C. utilis } & \text { Candida utilis } \\ \text { S. cerevisiae } & \text { Saccharomyces cerevisiae } \\ \text { S. uvarum } & \text { Saccharomyces uvarum } \\ \text { SD } & \text { Standard deviation } \\ \text { TEM } & \text { Transmission electron microscopy } \\ \text { YPD medium } & \text { Yeast Peptone Dextrose medium } \\ \text { YPD }+\mathrm{Mg}^{2+} & \text { YPD medium supplemented with } 1,25 \mathrm{~g} \\ & \text { of } \mathrm{Mg}^{2+} \text { per liter }\end{array}$

\section{Introductory remarks}

Yeast cells are, from the inside, enclosed with a cytoplasmatic membrane, periplasmatic space and cell wall successively. The yeast cell wall structure is mainly composed of polysaccharides of which content can constitute 20-90 \% of this organelle dry substance [22, 25, 29, 36]. Polysaccharides occurring in cell wall of the Saccharomyces genus are mainly $\beta$-glucans that make $30-60 \%$ of cell wall dry substance $[1,18,36]$. In yeast cell wall, two types of $\beta$-glucan polymers are present which differ in the glycosidic bond site between $\beta$-D-glucopyranose molecules that form those polymers. One type comprises a $\beta(1,3)$ glucan and the other a $\beta(1,6)$-glucan. It was found $[18,27]$ that $\beta(1,3)$-glucans are composed of about $1,500 \beta$-Dglucopyranose subunits. It makes approximately $85 \%$ of 
S. cerevisiae yeast cell wall glucans. The $\beta(1,6)$-glucan polymers are made up of about $130-150$ glucose subunits. Their proportion in cell wall structure amounts to nearly $15 \%[1,3,27]$. The $\beta(1,3)$-glucan chains are linked together by $\beta(1,6)$-glucan. The formation of covalent bonds with chitin causes $\beta$-glucan insolubility in bases, which is the foundation for their isolation and fractionation $[6,17$, 24, 34]. Kath and Kulicke [18] stated that $\beta$-glucans insoluble in bases make $80-85 \%$ of yeast cell wall glucans. They contain first of all $\beta(1,3)$-glycosidic bonds and approximately $3 \%$ of $\beta(1,6)$-glycosidic bonds, whereas their molecular mass is about $240 \mathrm{kDa}$. Glucans soluble in bases, which have a mass of about $250 \mathrm{kDa}$, make $15-20 \%$ of $\beta$-glucan total content. The $\beta(1,3)$-glycosidic bonds also predominate in their chain while subunits linked together by $\beta(1,6)$-glycosidic bonds constitute $8-12 \%$ of all bonds.

The second important group of yeast cell wall structural compounds is mannoproteins (phosphopeptidemannan). Mannoproteins can make $20-50 \%$ of cell wall dry substance [18]. They are a heterogeneous group of glycoproteins. There were about 40 different proteins of that type identified [35]. The carbohydrate fraction can constitute even up to $90 \%$ of such a glycoprotein molecule. The oligosaccharidic fragment is formed mainly by mannose polymers (mannan). The glucomannan, which is a mannan chemotype, was detected in the cell wall of $C$. utilis. The peptide fragment in mannoproteins makes $3-50 \%$ of a molecule, whereas phosphorus nearly $2 \%[7,18,26]$. In yeast cell wall, also $\mathrm{N}$-acetylglucosamine polymers (chitin) occur. It constitutes up to $4 \%$ of cell wall dry substance [1].

The first stage of metal ion binding in micro-organism cells does not depend on their metabolism and consists in an ion chemisorption into cell wall components. The cell wall structure determines the interaction nature between micro-organism and metal cation. Among other things, it is associated with the charge accumulated on cell surface or the kind of functional groups involved in bonds as well as cell surface hydrophobicity [23]. The cell wall structure is different in various micro-organisms, species or even strains, which brings about a differentiation in adsorption ability and capacity, affinity and interaction specificity. The passive mechanism of chemisorption may take place through an ion exchange, ion co-ordination or ion complexing, chelate formation, physical adsorption (e.g., electrostatic interactions) or microprecipitation [28, 33]. Such processes occur both in living cells and in metabolically inactive biomasses (e.g., thermally inactivated in pasteurization processes). Dead cells of micro-organisms have usually a greater ability to bind metal ions from the environment $[23,38]$. In the metal ion binding by yeasts, the mannoproteins present in the cell wall external layer as well as $\beta$-glucans and chitin are involved [5, 10].
Chemisorption takes place through interactions between metal ions and functional groups of compounds that form cells (carboxyl, phosphor, amine, hydroxyl, sulphydryl, carbonyl groups). Cell wall components play an essential part in that process [34]. According to the Hard and Soft Acid Base Principle, the $\mathrm{Na}^{+}, \mathrm{Ca}^{2+}$ and $\mathrm{Mg}^{2+}$ cations, socalled hard ions, can form ionic character bonds with ligands that contain oxygen, that is, $\mathrm{OH}^{-}, \mathrm{HPO}_{4}{ }^{2-}, \mathrm{CO}_{3}{ }^{2-}$, $\mathrm{RCOO}^{-}$and $=\mathrm{C}=\mathrm{O}$ groups. On the other hand, ions that are called soft (heavy metal cations, for example $\mathrm{Hg}^{2+}$ and $\mathrm{Pb}^{2+}$ ) form strong covalent bonds with groups containing nitrogen or sulfur $\left(-\mathrm{CN}^{-},-\mathrm{RS}^{-},-\mathrm{SH}^{-},-\mathrm{NH}_{2}{ }^{-}\right)$.

After the quick phase of cation binding to cell wall external structure begins a slow cation transport into the cytosol through active absorption. The absorption requires an expenditure of energy of the cell [14].

The ability to bind cations from cultivation media, including magnesium biosorption, creates a possibility of bioplex production. Magnesium cations bound in bioplexes, that is, through organic compounds, are characterized by better bio-availability in the alimentary tract in comparison with inorganic supplements and other elements [2].

The objective of the presented investigations was to determine the effect of cell wall structure in selected yeast species on the ability to bind magnesium ions by tested fungi biomass. The scope of this paper included a cultivation of selected yeasts of the Saccharomyces and Candida genera in experimental media supplemented with magnesium ions. An analysis of cell wall structural build, taking into account the mannoprotein and glucan content in yeasts coming from experimental systems, was performed. The amount of magnesium bound to biomasses of tested strains was also analyzed.

\section{Materials and methods}

Biological material and conditions of cultivation

The tested micro-organisms were three strains of yeast: S. cerevisiae No. 1 (brewer's yeast), S. cerevisiae 102 (baker's yeast) and C. utilis ATCC 9950 (fodder yeast). The strains came from a collection of pure culture at the Department of Biotechnology and Microbiology, Warsaw University of Life Sciences in Warsaw.

The following cultivation media were used in the tests: control medium - a fluid YPD medium containing $20 \mathrm{~g} / \mathrm{L}$ of peptone, $20 \mathrm{~g} / \mathrm{L}$ of glucose and $10 \mathrm{~g} / \mathrm{L}$ of yeast extract. Two types of experimental media were used. One medium was prepared by supplementing a YPD medium with magnesium ions $\left(1.25 \mathrm{~g}\right.$ of $\left.\mathrm{Mg}^{2+} / \mathrm{L}\right)$ of which source was $\mathrm{MgSO}_{4} \times 7 \mathrm{H}_{2} \mathrm{O}$. The other experimental medium was a solution of magnesium ions $\left(1.25 \mathrm{~g}\right.$ of $\left.\mathrm{Mg}^{2+} / \mathrm{L}\right)$ in 
deionized water. The active acidity of media was set at the level of 5.0. In the three test series, the control and experimental media $\left(90 \mathrm{~cm}^{3}\right)$ were prepared in $500-\mathrm{cm}^{3}$ flasks and they were inoculated using $10 \%(\mathrm{v} / \mathrm{v})$ of inoculum. The inoculum was collected from a $22-24 \mathrm{~h}$ yeast cultivation in YPD medium $\left(\mathrm{OD}_{\lambda=600 \mathrm{~nm}}\right.$ of about 2.0, BioRad Smart Spec 3000). The yeast biomass appropriated for an inoculum was rinsed twice with sterile deionized water, each time being centrifuged (3,500 rpm/10 min, Eppendorf Centrifuge $5804 \mathrm{R}$ ) and then suspended in deionized water. Parallelly, yeast biomass after thermal inactivation (pasteurization, $80^{\circ} \mathrm{C} / 30 \mathrm{~min}$ ) was applied as an inoculum. The magnesium biosorption process was performed for $24 \mathrm{~h}$ at the temperature of $28{ }^{\circ} \mathrm{C}$ with a 200 cycles/min shaking (Edmund Büchler SM-30 Control).

\section{Determination of cell biomass yield}

In order to determine the yeast biomass yield, $10 \mathrm{~cm}^{3}$ of cultivation medium (control or experimental) after $24 \mathrm{~h}$ incubation was centrifuged $(5,000 \mathrm{rpm} / 10 \mathrm{~min})$. The centrifuged biomass was rinsed with deionized water and then dried at the temperature of $80{ }^{\circ} \mathrm{C}$ till achieving a constant mass. The biomass yield was stated in $\mathrm{g}$ of yeast dry substance adjusted to a one liter of cultivation medium basis ( $\mathrm{g}$ of dry substance/L of medium).

Determination of magnesium content in cell biomass using atomic absorption spectrometry (ASA)

The samples $\left(10 \mathrm{~cm}^{3}\right)$ for magnesium content determination in yeast biomass from control and experimental cultivations were collected in the following time sequences: T0-directly from the inoculum before it was placed in the cultivation medium, T6-after a six-hour cultivation, T24-after a twenty-four-hour cultivation. The centrifuged yeast biomass $(5,000 \mathrm{rpm} / 10 \mathrm{~min})$ was rinsed with sterile deionized water, centrifuged and then dried at the temperature of $80{ }^{\circ} \mathrm{C}$ till achieving a constant mass. Weighed portions of yeast dry biomass were mineralized in a mixture of nitric acid and perchloric acid (Büchi Digestion Unit K-435). Magnesium content in the mineralized portions was determined with the use of an atomic absorption spectrometer (SHIMADZU AA-600) at the $\lambda=285.2 \mathrm{~nm}$ wavelength. The results were stated in $\mathrm{mg}$ of magnesium adjusted to a $1 \mathrm{~g}$ of yeast dry substance basis $\left(\mathrm{mg}\right.$ of $\mathrm{Mg}^{2+} / \mathrm{g}$ of dry substance).

Determination of yeast cell wall yield

The tested yeast strains for cell wall content and cell wall structural components determinations were grown in YPD media and YPD media supplemented with magnesium ions at a dose of $1.25 \mathrm{~g} / \mathrm{L}$. The cultivations were carried out till achieving the $\mathrm{OD}_{\lambda=600 \mathrm{~nm}}=2.0$ (for about $24 \mathrm{~h}$ ). Cell wall specimens were obtained by a twenty-four-hour autolysis of tested yeast strains cells at the temperature of $50{ }^{\circ} \mathrm{C}[11$, $38]$. Autolyzed cells were centrifuged $(11,000 \mathrm{rpm} / 15 \mathrm{~min} /$ $4{ }^{\circ} \mathrm{C}$ ) and rinsed with sterile deionized water three times. It was assumed that centrifuged deposits contained yeast cell wall fragments, which during the next phase, were dried $\left(80{ }^{\circ} \mathrm{C} / 24 \mathrm{~h}\right)$. The cell wall proportion in dry substance of cellular biomass of tested yeast strains was determined on the grounds of the difference in content of dry substance of cellular biomass before and after the autolysis process.

Determination of mannoprotein and $\beta$-glucan fractions in yeast cell wall

Obtained yeast cell wall specimens were subjected to a fractionation into respective structural polysaccharides, that is, $\beta(1,3)$-glucan, $\beta(1,6)$-glucan and mannoproteins (fractions indicated as No. 1-6 in Fig. 1). The methodology of yeast cell wall structural polymer fractionation was based on procedures described in the literature $[6,9,31$, 37]. Because of the small content of $\beta$-glucans soluble in bases, those compounds were not subjected to an additional separation of $\beta(1,3)$-glucan from $\beta(1,6)$-glucan, but there was only made an assumption that they are $\beta(1,3)$-glucan polymers. Fractions of polymers insoluble in bases were subjected to enzymatic hydrolysis with the Zymolyase-20T preparation, MP Biomedicals LLC [30, 32]. The deposit from alkaline hydrolysis was neutralized by rinsing it twice with TRIS- $\mathrm{HCl}(0.1 \mathrm{M}$ buffer and then $0.01 \mathrm{M}$ buffer, $\mathrm{pH}$ 7.4). The enzymatic hydrolysis was carried out at the temperature of $37{ }^{\circ} \mathrm{C}$ for $24 \mathrm{~h}$ by means of a $5 \mathrm{mg} / \mathrm{cm}^{3}$ enzyme solution prepared in a $0.01 \mathrm{M}$ TRIS-HCl buffer (pH 7.4). Afterward the deposit was centrifuged $(14,000$ $\mathrm{rpm} / 15 \mathrm{~min}$ ) and the supernatant subjected to a twentyfour-hour dialysis (SIGMA-ALDRICH: dialysis tubing, high retention seamless cellulose tubing, MWCO 12400, $99.99 \%$ retention). The aim of this procedure was to separate $\beta(1,6)$-glucan from hydrolyzed $\beta(1,3)$-glucan. The total sugar content (in terms of glucose) in yeast cell wall was determined directly in cell wall specimens by performing a cell wall polymer acid hydrolysis with a $6 \mathrm{M}$ $\mathrm{HCl}\left(100{ }^{\circ} \mathrm{C} / 4 \mathrm{~h}\right)$ [30]. The reducing sugar content was analyzed with a colorimetric method using 3,5-dinitrosalicylic acid.

The content of polysaccharide fractions obtained by means of basic extraction, enzymatic hydrolysis and dialysis (fractions indicated as No 1-6 in Fig. 1) was also stated in terms of reducing sugar (glucose) content after acid hydrolysis.

The $\beta(1,3)$-glucan content in the fraction insoluble in bases was determined from the difference in fraction 2 


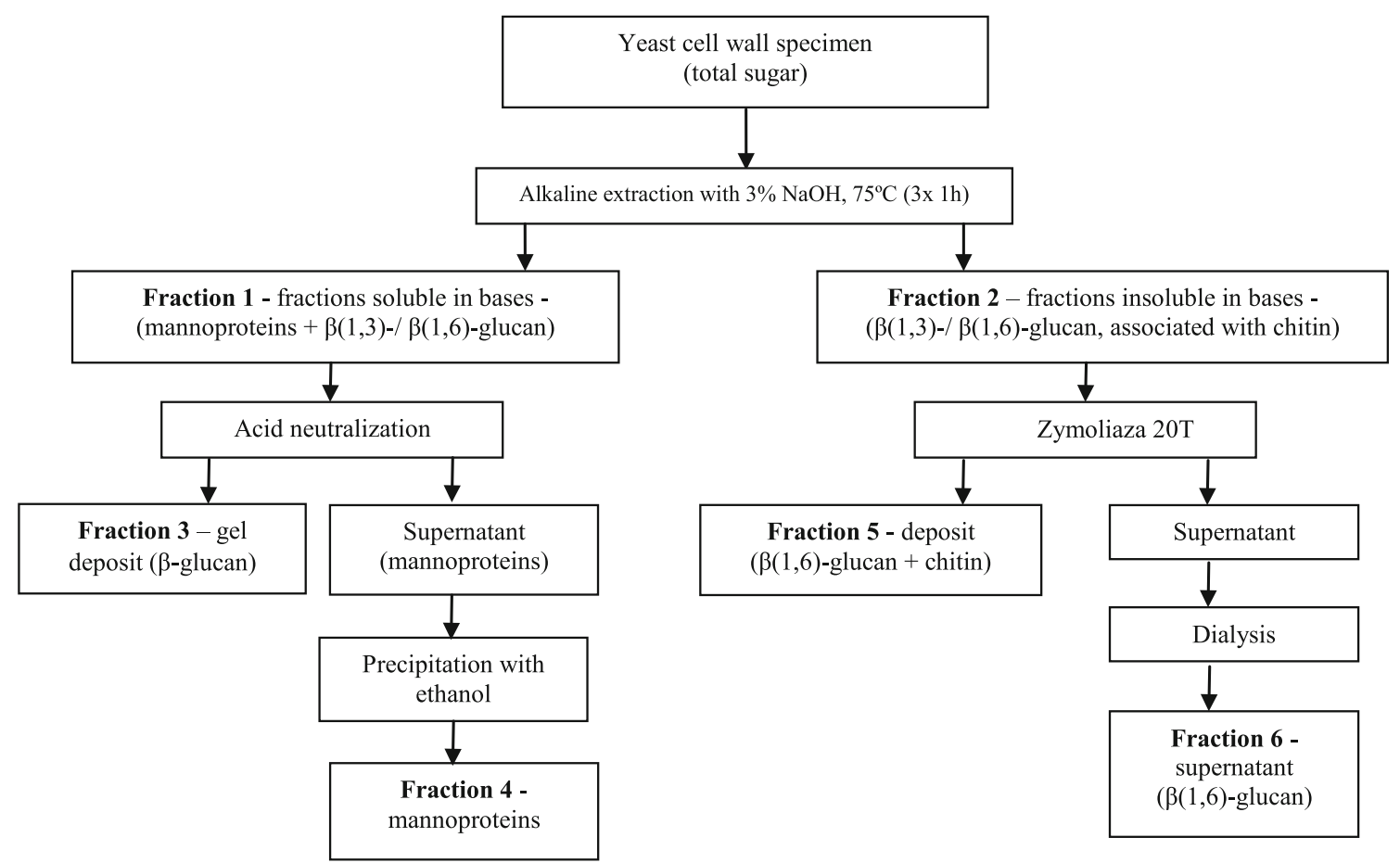

Fig. 1 Procedure of yeast cell wall structural component fractionation

sugar content and the $\beta(1,6)$-glucan content (sum of fraction 5 and 6). In calculations concerning fraction 5 was assumed that there is only $\beta(1,6)$-glucan. For fraction 3 was assumed that it is only $\beta(1,3)$-glucan [32].

Measurement of yeast cell wall thickness using transmission electron microscopy (TEM)

The objective of this investigation phase was to determine the yeast cell wall total thickness, as well as the mannoprotein and glucan layer thickness. For microscopic observations, yeast biomass specimens were collected after a twenty-four-hour cultivation. Measurements of yeast cell wall thickness, mannoprotein and $\beta$-glucan layer thickness were taken on the grounds of photographs made with the TEM (JEM-1220 type JOEL). To prepare yeast biomass for microscopic observations, it was necessary to fix yeast cells in a glutaraldehyde prepared in phosphate buffer $(\mathrm{pH}=7.2)$. Then, the specimens were fixed in an osmium solution $\left(\mathrm{OsO}_{4}\right)$. Further procedure phases were as follows: preparation rinsing with water, dehydration with ethanol, embedding in Epon resin, cutting sections by means of an ultramicrotome (LKB) and contrasting with uranyl acetate and lead acetate [12].

\section{Statistical analysis}

The obtained results were subjected to a statistical analysis using the STATISTICA V.8 program. An analysis with the
ANOVA method (NIR Fisher's test or Tukey's test) was carried out at the $\alpha=0.05$ level of significance.

\section{Results and discussion}

Yeast cell wall thickness

On the grounds of tested yeast strain photographs (Fig. 2), made by means of the TEM after twenty-four-hour incubation of cells in experimental media, the thickness of cell wall as well as mannoprotein and glucan layers were measured.

Tested strains achieved the thickest cell wall after cultivation in YPD + Mg medium inoculated with living cells of fungi (approx. $160 \mathrm{~nm}$ in S. cerevisiae 102, approx. $219 \mathrm{~nm}$ in S. cerevisiae No. 1, approx. $170 \mathrm{~nm}$ in C. utilis ATTC 9950)-Table 1. This was associated with the presence of nutritive components necessary in the synthesis of both glucan and mannoprotein layers. It makes a reorganization of that organelle by metabolically active yeast possible. One should presume that cell wall thickness resulted not only from the amount of structural substances but also their spatial packing. The thickest cell wall in the media without added magnesium was observed in $C$. utilis inocula, where the measurement result was about $140 \mathrm{~nm}$. That result in both $S$. cerevisiae strains amounted to about $130 \mathrm{~nm}$. It can be concluded that magnesium addition to YPD medium resulted in a significant increase in tested 

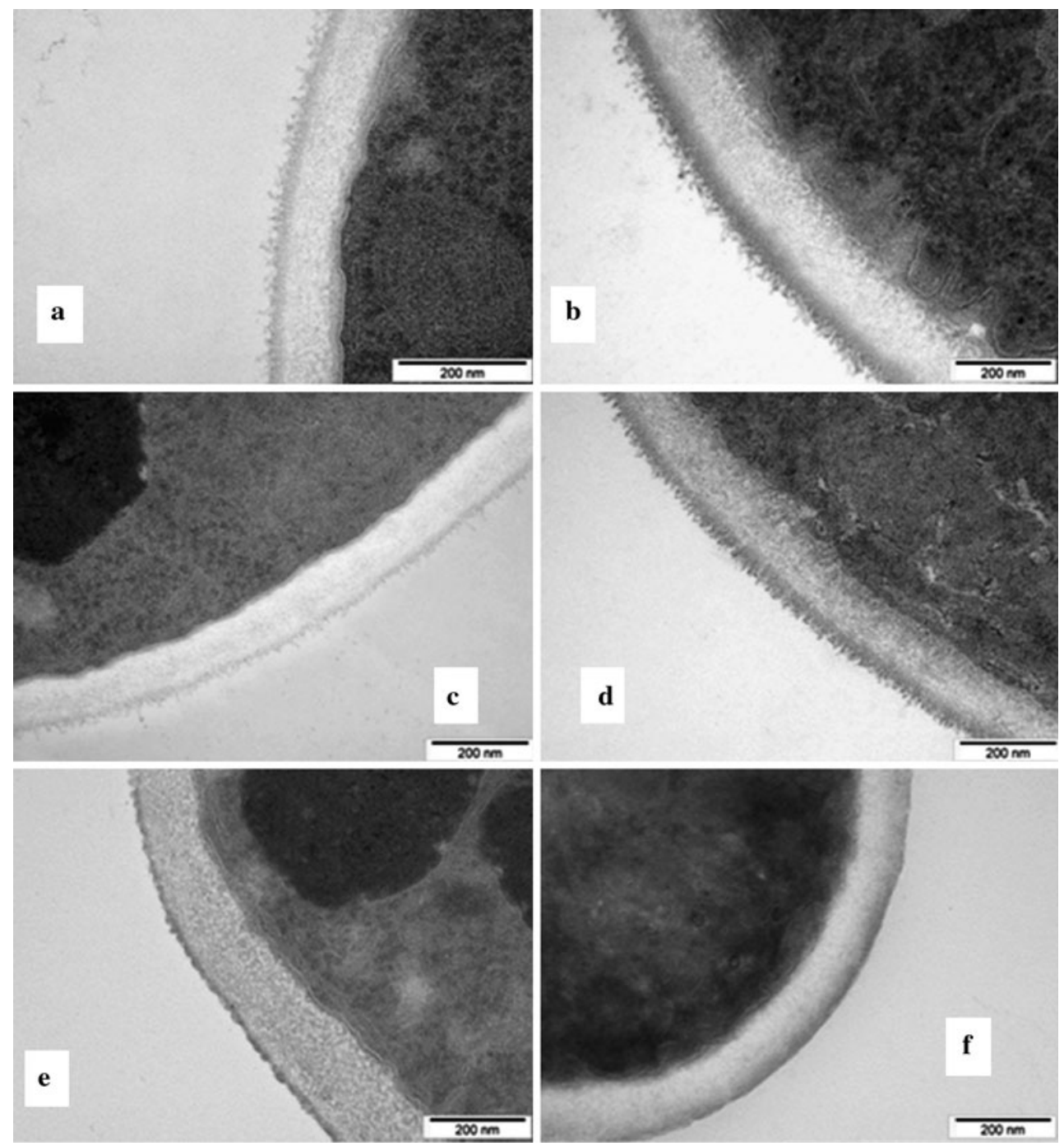

Fig. 2 Exemplary microscopic (TEM) photographs of S. cerevisiae $102(\mathbf{a}, \mathbf{b})$, S. cerevisiae No. 1 (c, d) and C. utilis ATCC 9950 (e, f) yeast living cell walls from YPD and YPD $+\mathrm{Mg}^{2+}$ media, respectively

yeast cell wall thickness. The greatest increase in cell wall thickness (approx. $66 \%$ ) was observed in the $S$. cerevisiae No. 1 strain. The cell wall thickness in cells making the inoculum (YPD medium) was $132 \mathrm{~nm}$, whereas after incubation in YPD medium supplemented with magnesium that value increased up to $219 \mathrm{~nm}$.

The analysis of cell walls of pasteurized biomass has demonstrated an increase in cell wall thickness in comparison with results obtained for living cells from YPD medium. This could result from a structure loosening under the influence of high temperature. Heat treatment of yeast biomass brought about a disruption of some of the bonds in the mannoprotein layer and glucan network and resulted in a cell wall structure loosening. The cell wall structure loosening could facilitate $\mathrm{Mg}^{2+}$ ion access and therefore in systems with pasteurized biomasses a greater ability to bind magnesium cations was found.
Unlike living cells, in which an increased growth of cell wall thickness was observed in YPD $+\mathrm{Mg}^{2+}$ medium, in pasteurized cells such a process took place in $\mathrm{MgSO}_{4}$ solution. The cell wall thickness in S. cerevisiae No. 1, S. cerevisiae 102 and C. utilis ATCC 9950 was 175, 155 and $157 \mathrm{~nm}$, respectively. In a comparison between those results and control tests (inoculum biomass: 132, 129 and $140 \mathrm{~nm}$ ), the increase in cell wall thickness in the abovementioned strains was 32,20 and $12 \%$, respectively. The cell wall thickness as well as mannoprotein and $\beta$-glucan layer proportion in tested yeast cell walls turned out to depend on species and strain.

The greatest mannoprotein proportion in cell wall structure (approx. $38 \%$ ) featured the S. cerevisiae 102 baker's yeast after cultivation in YPD $+\mathrm{Mg}^{2+}$ medium (that layer mean thickness was about $54 \mathrm{~nm}$ ). At the same time, the smallest amounts of $\beta$-glucans (62\%) were found 
Table 1 Mean thickness of S. cerevisiae No. 1, S. cerevisiae 102 and C. utilis ATCC 9950 cell wall, mannoprotein layer and glucan layer in YPD media and YPD $+\mathrm{Mg}^{2+}$ after $24 \mathrm{~h}$ cultivation

* Means with the same letter $a, b, c$... considering one strain of yeasts did not differ significantly (acc. to Tukey's test)

\begin{tabular}{|c|c|c|c|}
\hline Medium & $\begin{array}{l}\text { Cell wall } \\
(\mathrm{nm}) \pm \mathrm{SD}\end{array}$ & $\begin{array}{l}\text { Mannoprotein layer } \\
(\mathrm{nm}) \pm \mathrm{SD} \\
(\% \text { of cell wall })\end{array}$ & $\begin{array}{l}\beta \text {-Glucan layer } \\
(\mathrm{nm}) \pm \mathrm{SD} \\
(\% \text { of cell wall })\end{array}$ \\
\hline \multicolumn{4}{|l|}{ S. cerevisiae 102} \\
\hline YPD & $129 \pm 6 \mathrm{a}^{*}$ & $31 \pm 4(26) \mathrm{a}$ & $91 \pm 7(74) \mathrm{c}$ \\
\hline $\mathrm{YPD}+1.25 \mathrm{~g}$ of $\mathrm{Mg}^{2+} / \mathrm{L}$ & $160 \pm 14 b$ & $54 \pm 13(38) b$ & $111 \pm 10(62) \mathrm{a}$ \\
\hline \multicolumn{3}{|l|}{ Biomass after pasteurization } & $78 \pm 8(72) b$ \\
\hline $\mathrm{YPD}+1.25 \mathrm{~g}$ of $\mathrm{Mg}^{2+} / \mathrm{L}$ & $134 \pm 11 \mathrm{a}$ & $33 \pm 11(29) \mathrm{a}$ & $102 \pm 11(71) \mathrm{a}$ \\
\hline $\begin{array}{l}1.25 \mathrm{~g} \text { of } \mathrm{Mg}^{2+} / \mathrm{L} \text { solution } \\
\text { S. cerevisiae No. } 1\end{array}$ & $155 \pm 18 \mathrm{~b}$ & $27 \pm 6(18) a$ & $123 \pm 14(82) d$ \\
\hline YPD & $132 \pm 8 b$ & $28 \pm 5(21) \mathrm{a}$ & $105 \pm 9(79) \mathrm{c}$ \\
\hline $\mathrm{YPD}+1.25 \mathrm{~g}$ of $\mathrm{Mg}^{2+} / \mathrm{L}$ & $219 \pm 17 \mathrm{~d}$ & $32 \pm 5(15) a, b$ & $184 \pm 12(85) d$ \\
\hline \multicolumn{3}{|l|}{ Biomass after pasteurization } & $145 \pm 12(78) b$ \\
\hline $\mathrm{YPD}+1.25 \mathrm{~g}$ of $\mathrm{Mg}^{2+} / \mathrm{L}$ & $157 \pm 17 \mathrm{c}$ & $33 \pm 10(20) a, b, c$ & $127 \pm 15(80) \mathrm{a}$ \\
\hline $\begin{array}{l}1.25 \mathrm{~g} \text { of } \mathrm{Mg}^{2+} / \mathrm{L} \text { solution } \\
\text { C. utilis ATCC } 9950\end{array}$ & $175 \pm 12 \mathrm{a}$ & $37 \pm 7(21) b, c$ & $134 \pm 14(79) a, b$ \\
\hline YPD & $140 \pm 10 \mathrm{a}, \mathrm{b}$ & $21 \pm 7(16) \mathrm{a}$ & $117 \pm 16(84) \mathrm{a}$ \\
\hline $\mathrm{YPD}+1.25 \mathrm{~g}$ of $\mathrm{Mg}^{2+} / \mathrm{L}$ & $170 \pm 15 \mathrm{~d}$ & $25 \pm 4(18) a, b$ & $144 \pm 14(82) \mathrm{a}$ \\
\hline \multicolumn{3}{|l|}{ Biomass after pasteurization } & $114 \pm 11(82) \mathrm{a}$ \\
\hline $\mathrm{YPD}+1.25 \mathrm{~g}$ of $\mathrm{Mg}^{2+} / \mathrm{L}$ & $151 \pm 12 \mathrm{~b}, \mathrm{c}$ & $30 \pm 8(20) b$ & $127 \pm 12(80) \mathrm{a}, \mathrm{b}$ \\
\hline $1.25 \mathrm{~g}$ of $\mathrm{Mg}^{2+} / \mathrm{L}$ solution & $157 \pm 13 \mathrm{c}, \mathrm{d}$ & $24 \pm 5$ (12) a,b & $140 \pm 11(88) b, c$ \\
\hline
\end{tabular}

in those cells (layer thickness was $111 \mathrm{~nm}$ ). In the same experimental medium, the $S$. cerevisiae No. 1 strain was characterized by an approx. 32-nm-thick mannoprotein layer, which made $15 \%$ of cell wall thickness. In that strain, an increase in mannoprotein layer thickness did not result in an increase in its proportion, since the cell wall was thicker $(219 \mathrm{~nm})$ in comparison with inoculum cell wall $(132 \mathrm{~nm})$. The $\beta$-glucan turned out to be a cell wall predominating polymer in those yeasts $(184 \mathrm{~nm}$, which made $85 \%$ of cell wall thickness). In C. utilis ATTC 9950 living cells after incubation in YPD $+\mathrm{Mg}^{2+}$ media, a mannoprotein and $\beta$-glucan proportion was found to be similar to that one determined in $S$. cerevisiae cell wall structure (18 and $82 \%$ for 25 and $144 \mathrm{~nm}$ thickness, respectively).

The analysis of results of mannoprotein and glucan layer proportion in cell wall in each strain after living biomass incubation in experimental media was shown a differentiated cell response to cultivation conditions. An addition of magnesium ions caused an intensification of mannoprotein synthesis in $S$. cerevisiae 102 cells, which resulted in an increase in this layer proportion in cell wall structure $\left(54 \mathrm{~nm}\right.$ in YPD $+\mathrm{Mg}^{2+}$ medium, $31 \mathrm{~nm}$ in YPD medium). On photographs of S. cerevisiae 102 cells (Fig. 2) from YPD $+\mathrm{Mg}$ medium, a thicker and more distinct mannoprotein layer was visible in comparison with the control cultivation (YPD). The most conspicuous change concerning the $\mathrm{MgSO}_{4}$ solution was a smoother surface of mannoprotein layer, which had a very irregular form, in the control cultivation. This may indicate that $\mathrm{Mg}^{2+}$ ions influenced packing and by that also cell wall structural polymers spatial structure in the fungi. A small increase in mannoprotein proportion (about $2 \%$ ) was found also in C. utilis species cell wall (increase in thickness from 21 to $25 \mathrm{~nm}$ ). S. cerevisiae No. 1 strain cells behaved differently in this respect. Despite the increase in mannoprotein layer thickness from 28 to $32 \mathrm{~nm}$, its proportion in cell wall diminished from 21 to $15 \%$, whereas the glucan layer increased from 79 to $85 \%$ (increase in thickness from 105 to $184 \mathrm{~nm}$ ). This dependence was connected with the increase in cell wall thickness in the yeast strain discussed above. In cell walls of yeast strains incubated in magnesium sulfate solution as a living biomass, the mannoprotein and glucan proportion remained at the same level as in cells cultivated in YPD medium. An incubation of $S$. cerevisiae 102 and $C$. utilis pasteurized biomass in a solution containing magnesium ions caused a decrease in mannoprotein layer proportion in cell wall in comparison with its proportion in inoculum cultivation cells (from 26 to $18 \%$ and from 16 to $12 \%$, respectively). Such effect was not found in thermally treated biomass of the strain incubated in YPD $+\mathrm{Mg}^{2+}$ medium. Perhaps, in the first case, water- 
soluble mannoproteins penetrated more easily from the disintegrated yeast biomass into the solution. This brought about an increase in insoluble $\beta$-glucan proportion in cell wall structure (from 74 to $82 \%$ and from 84 to $88 \%$, respectively).

Summarizing, magnesium ions added to experimental media induced an increase in cell wall thickness in tested yeast strains. However, in the analysis of mannoprotein and glucan layer proportions in cell wall in each of the yeast strains, a differentiated cell response to cultivation conditions was found. Pasteurization brought about a cell wall structure loosening that resulted in an increase in cell wall thickness.

Yeast cell wall chemical composition

The aim of this phase of investigation was a determination of cell wall structure changes in tested yeasts in relation to cultivation conditions. The effect of individual structural elements (taking $\beta$-glucans and mannoproteins into account) on the tested strain ability to bind magnesium was studied. Only living yeast cells incubated in YPD or YPD $+\mathrm{Mg}^{2+}$ medium, showing growth under such conditions, were subjected to the analyses.

Irrespective of used cultivation media, the cell wall proportion in dry substance of biomass of tested yeast strain was within the range of $25-28 \%$, and ascertained differences were not significant (Table 2). According to data in the literature $[1,19,30]$, yeast cell wall makes approximately 10-30\% of cellular biomass dry substance.
The cell wall in $S$. cerevisiae 102 baker's yeast cultivated in YPD medium (biomass used as an inoculum) contained approx. $38 \%$ sugars in terms of glucose (Table 3). In cells of the same strain but from YPD $+\mathrm{Mg}^{2+}$ medium, about $41 \%$ sugar content in the analyzed organelle was determined; however, the difference was not significant in comparison with the inoculum. The S. cerevisiae 102 yeast was characterized by the highest cell wall mannoprotein content, approx. 63 and $66 \%$ in YPD and YPD $+\mathrm{Mg}^{2+}$ medium, respectively, and the lowest $\beta$-glucan content. The lower total sugar content in baker's yeast cell wall can give an explanation for higher mannoprotein content. The results of measurements of mannoprotein and glucan layer thickness in S. cerevisiae 102 cell wall also confirmed the highest glycoprotein content in the structure of the organelle at issue in that strain. The chemical analysis allowed to ascertain that $\beta(1,3)$-glucan prevailed in the $S$. cerevisiae 102 cell wall $\beta$-glucan fraction (84 and $86 \%$ in cells from YPD and YPD medium supplemented with magnesium). Insignificant changes in total sugar content were found in cell wall of $C$. utilis from YPD and YPD $+\mathrm{Mg}^{2+}$ medium; however, its cell wall contained the greatest polysaccharide proportion, that is, approx. $90 \%$. The C. utilis yeast was also characterized by the highest $\beta$-glucan content (69 and $78 \%$ total sugar, respectively). A similar tendency was noticed in the analysis of photographs taken by means of TEM microscopy. The obtained results of a $C$. utilis species cell wall chemical analysis indicated a significant increase in glucan content and a decrease in mannoprotein

Table 2 The cell wall, $\beta$-glucan and mannoprotein content in S. cerevisiae No. 1, S. cerevisiae 102 and $C$. utilis ATCC 9950 cultivated for $24 \mathrm{~h}$ on YPD media and YPD $+\mathrm{Mg}^{2+}$ after $24 \mathrm{~h}$ cultivation

\begin{tabular}{|c|c|c|c|c|c|}
\hline $\begin{array}{l}\text { Strain and } \\
\text { medium }\end{array}$ & $\begin{array}{l}\text { Cell wall (\% of } \\
\text { cell dry mass) }\end{array}$ & $\begin{array}{l}\text { Mannoprotein (\% of cell } \\
\text { wall total carbohydrates) }\end{array}$ & $\begin{array}{l}\beta \text {-Glucan (\% of cell wall } \\
\text { total carbohydrates) }\end{array}$ & $\begin{array}{l}\beta(1,3) \text {-Glucan (\% of cell } \\
\text { wall total carbohydrates) }\end{array}$ & $\begin{array}{l}\beta(1,6)-\text { Glucan (\% of cell } \\
\text { wall total carbohydrates) }\end{array}$ \\
\hline \multicolumn{6}{|l|}{ S. cerevisiae 102} \\
\hline YPD medium & $26.0 \pm 1.4 \mathrm{~A}$ & $63.2 \pm 1.0 \mathrm{a}$ & $36.8 \pm 3.3 \mathrm{a}$ & $\begin{array}{l}30.9 \pm 3.1 \mathrm{a}^{* *} \\
(83.9)^{*}\end{array}$ & $\begin{array}{l}5.9 \pm 0.2 \mathrm{a} \\
(16.1)\end{array}$ \\
\hline $\begin{array}{l}\text { YPD }+1.25 \mathrm{~g} \\
\text { of } \mathrm{Mg}^{2+} / \mathrm{L}\end{array}$ & $25.0 \pm 2.6 \mathrm{~A}$ & $66.0 \pm 1.2 \mathrm{~b}$ & $34.0 \pm 0.5 \mathrm{a}$ & $\begin{array}{l}29.2 \pm 0.5 \mathrm{a} \\
(85.9)\end{array}$ & $\begin{array}{l}4.8 \pm 0.2 \mathrm{a} \\
(14.1)\end{array}$ \\
\hline \multicolumn{6}{|l|}{ S. cerevisiae No. 1} \\
\hline YPD medium & $27.7 \pm 2.1 \mathrm{~A}$ & $54.4 \pm 0.2 \mathrm{a}$ & $45.6 \pm 0.4 \mathrm{a}$ & $\begin{array}{l}35.1 \pm 0.7 \mathrm{a} \\
(76.9)\end{array}$ & $\begin{array}{l}10.5 \pm 0.3 \mathrm{a} \\
(23.1)\end{array}$ \\
\hline $\begin{array}{l}\text { YPD }+1.25 \mathrm{~g} \\
\text { of } \mathrm{Mg}^{2+} / \mathrm{L}\end{array}$ & $28.0 \pm 3.5 \mathrm{~A}$ & $48.8 \pm 4.4 \mathrm{a}$ & $51.7 \pm 0.8 \mathrm{~b}$ & $\begin{array}{l}42.8 \pm 0.5 \mathrm{~b} \\
(82.7)\end{array}$ & $\begin{array}{l}8.9 \pm 0.3 \mathrm{a} \\
(17.3)\end{array}$ \\
\hline \multicolumn{6}{|c|}{ C. utilis ATCC 9950} \\
\hline YPD medium & $26.0 \pm 1.5 \mathrm{~A}$ & $31.4 \pm 0.7 \mathrm{a}$ & $68.6 \pm 3.6 \mathrm{a}$ & $\begin{array}{l}39.4 \pm 4.0 \mathrm{c}, \mathrm{d} \\
(57.4)\end{array}$ & $\begin{array}{l}29.3 \pm 2.2 \mathrm{a} \\
(42.6)\end{array}$ \\
\hline $\begin{array}{l}\text { YPD }+1.25 \mathrm{~g} \\
\text { of } \mathrm{Mg}^{2+} / \mathrm{L}\end{array}$ & $28.3 \pm 2.1 \mathrm{~A}$ & $21.6 \pm 4.4 \mathrm{~b}$ & $78.4 \pm 3.0 \mathrm{~b}$ & $\begin{array}{l}36.9 \pm 1.7 \mathrm{~b}, \mathrm{c}, \mathrm{d} \\
(47.0)\end{array}$ & $\begin{array}{l}41.6 \pm 0.2 \mathrm{~b} \\
(53.0)\end{array}$ \\
\hline
\end{tabular}

\footnotetext{
* Percentage of total $\beta$-glucan content

** Means with the same letters a,b,c ... considering one strain of yeasts did not differ significantly (acc. to NIR Fisher's test)
} 
content in the cell wall following a cell cultivation in YPD $+\mathrm{Mg}^{2+}$ medium. In cells of $C$. utilis from YPD medium, the $\beta(1,3)$-glucan and $\beta(1,6)$-glucan proportion in those polymers total content amounted to $57 \%$ and approx. $43 \%$, respectively. In a medium supplemented with magnesium cations, the glucan fraction proportions were reversed, that is, approx. $47 \% \beta(1,3)$-glucan and approx. $53 \% \beta(1,6)$-glucan. This could have an effect on glucose polymer spatial organization in those yeast cell wall structure, as well as physical and chemical properties.

The addition of magnesium ions to YPD medium induced a significant increase in total sugar content only in S. cerevisiae No. 1. There was an increase shown in sugar content in that strain cell wall from about 51 to about $63 \%$. This was probably a result of increased $\beta$-glucan content in the cell wall structure, confirmed both in the chemical analysis of that polysaccharide fraction content and measurement of glucan layer thickness (Table 3).

After cultivation in YPD medium and media supplemented with magnesium, the content of mannoprotein in cell wall of S. cerevisiae No. 1 strain was about $54 \%$ and about $49 \%$ of cell wall total sugar content, respectively. The decrease in glycoprotein content proved to be insignificant. A similar tendency was noticed in measurements of $S$. cerevisiae No. 1 cell wall mannoprotein layer thickness. According to the literature [18], yeast cell wall mannoprotein content is within $20-50 \%$. The total $\beta$-glucan content in cell wall of $S$. cerevisiae No. 1 yeast amounted to approx. 46 and $52 \%$. Among $\beta$-glucans polymers of $S$. cerevisiae No. 1 cell wall, as in $S$. cerevisiae $102, \beta(1,3)$-glucan predominated (approx. 77 and $83 \%$ ), however, the $\beta(1,6)$ glucan proportion was greater comparing with $S$. cerevisiae 102 strain. The $\beta(1,6)$-glucan is a polymer that has a higher degree of branching and better solubility in water. The degree of $\beta$-glucan polymerization and branching, which

Table 3 The carbohydrate content in percent in cell wall dry substance of $S$. cerevisiae No. 1, S. cerevisiae 102 and C. utilis ATCC 9950 in YPD media and YPD $+\mathrm{Mg}^{2+}$ after $24 \mathrm{~h}$ cultivation

\begin{tabular}{ll}
\hline Strain and medium & $\begin{array}{l}\text { Carbohydrates } \\
(\% \text { of cell wall dry mass) }\end{array}$ \\
\hline $\begin{array}{l}\text { S. cerevisiae } 102 \\
\quad \text { YPD medium }\end{array}$ & $38.0 \pm 1.9 \mathrm{a}^{*}$ \\
$\quad$ YPD $+1.25 \mathrm{~g}$ of $\mathrm{Mg}^{2+} / \mathrm{L}$ & $41.1 \pm 2.3 \mathrm{a}$ \\
S. cerevisiae No. 1 & $50.8 \pm 4.4 \mathrm{~b}$ \\
$\quad$ YPD medium & $62.6 \pm 4.5 \mathrm{c}$ \\
YPD + $1.25 \mathrm{~g}$ of $\mathrm{Mg}^{2+} / \mathrm{L}$ & \\
C. utilis ATCC 9950 & $91.3 \pm 4.1 \mathrm{~d}$ \\
$\quad$ YPD medium & $89.7 \pm 0.8 \mathrm{~d}$ \\
YPD + $1.25 \mathrm{~g}$ of $\mathrm{Mg}^{2+} / \mathrm{L}$ &
\end{tabular}

* Means with the same letters a,b,c... did not differ significantly (acc. To NIR Fisher's test) determine active site accessibility to intermolecular interactions, is a yeast species quality, but it is affected also by the conditions of fungi growth $[3,21]$. Data from the literature [18, 27] confirm that $\beta(1,3)$-glucans prevail among $S$. cerevisiae yeast cell wall glucans. Similarly, the obtained results for tested yeast cell wall sugar were consistent with data in the literature [23, 25, 29, 36].

Glucose polymers present in yeast cell wall, that is, $\beta$-Dglucans, are organized in the form of a three-dimensional structure consisting of random coils, single helices and triple helices [20]. Between glucan side chains, hydrogen bonds are formed and they cause a coiling up of the molecule with helix formation. This process can be affected by glucose polymer degree of chain branching consequently. Molecules of chemical compound can penetrate the threedimensional structure of $\beta$-glucans, thereby interacting with hydroxyl groups of glucose that forms glucans. Single helices have the greatest number of potential binding sites, because they are not dense and compact molecules like triple helices. The not reducing ends of $\beta$-glucan can be a site for covalent links with other polysaccharides or other chemical compounds. Wang and Chen [38] state that free hydroxyl groups in glucose polymer chains play an essential part in magnesium ion binding. A decrease in yeast cell wall elasticity blocks the binding site accessibility. The amount of contained chitin, which decreases $\beta$-D-glucan solubility [16], may influence this as well.

On the grounds of results of mannoprotein and $\beta$-glucan content determination, we can presume that tested yeasts were characterized by a different spatial organization of the cell wall. However, this should be confirmed by means of more accurate analytical methods. Not only the respective polymer contents, but also the mannoprotein and $\beta$-glucan proportions as well as their structure (e.g., degree of branching) can have an effect on the ability to interaction of those compounds functional groups with substances present in yeast growth environment, including metal cations.

Depending on the cultivation medium, different tendencies of changes in contents of respective structural component of cell walls of tested yeast strains were observed. It renders an explicit interpretation of the effect of this organelle structure on magnesium binding difficult. However, we can presume that mannoproteins played an essential part in magnesium cation binding by $S$. cerevisiae 102 yeast, whereas $\beta$-glucans in $S$. cerevisiae No. 1 and C. utilis ATTC 9950. This hypothesis was handled in the next part of the discussion.

\section{Magnesium binding by yeast biomass}

Results of yeast biomass magnesium content determinations showed differences in the degree of magnesium binding by tested strains of fungi (Table 4). The initial 
Table 4 Magnesium content in dry biomass of S. cerevisiae No. 1, S. cerevisiae 102 and C. utilis ATCC 9950 after cultivation in YPD + Mg ${ }^{2+}$ and a solution of $\mathrm{Mg}^{2+} ; 0 \mathrm{~h}$-magnesium content in yeasts biomass after cultivation in YPD medium (inoculum)

\begin{tabular}{|c|c|c|c|c|}
\hline \multirow[t]{3}{*}{ Medium } & \multirow[t]{3}{*}{ Cultivation time $(\mathrm{h})$} & \multicolumn{3}{|c|}{ Magnesium content $\left(\mathrm{mg} \mathrm{Mg}^{2+} / \mathrm{g}\right.$ d.w. $) \pm \mathrm{SD}$} \\
\hline & & \multicolumn{3}{|l|}{ Strain } \\
\hline & & S. cerevisiae 102 & $\begin{array}{l}\text { S. cerevisiae } \\
\text { No. } 1\end{array}$ & $\begin{array}{l}\text { C. utilis } \\
\text { ATCC } 9950\end{array}$ \\
\hline \multicolumn{5}{|c|}{ Cultivation with not pasteurized biomass } \\
\hline \multirow[t]{3}{*}{$\mathrm{YPD}+1.25 \mathrm{~g}$ of $\mathrm{Mg}^{2+} / \mathrm{L}$} & 0 & $1.4 \pm 0.2 \mathrm{~b}, \mathrm{~A}^{*}$ & $2.9 \pm 0.3 \mathrm{a}, \mathrm{A}$ & $0.9 \pm 0.1 \mathrm{~b}, \mathrm{~A}$ \\
\hline & 6 & $2.8 \pm 0.2 \mathrm{a}, \mathrm{C}$ & $7.1 \pm 1.5 \mathrm{e}, \mathrm{B}$ & $4.4 \pm 1.1 \mathrm{~d}, \mathrm{~B}$ \\
\hline & 24 & $2.4 \pm 0.2 \mathrm{a}, \mathrm{C}$ & $2.7 \pm 0.6 \mathrm{a}, \mathrm{A}$ & $4.3 \pm 1.1 \mathrm{~d}, \mathrm{~B}$ \\
\hline \multirow[t]{3}{*}{$1.25 \mathrm{~g}$ of $\mathrm{Mg}^{2+} / \mathrm{L}$ solution } & 0 & $1.4 \pm 0.2 \mathrm{a}, \mathrm{A}$ & $3.2 \pm 1.4 \mathrm{~d}, \mathrm{~A}$ & $0.9 \pm 0.1 \mathrm{a}, \mathrm{A}$ \\
\hline & 6 & $8.0 \pm 0.8 \mathrm{c}, \mathrm{E}$ & $9.5 \pm 0.5 \mathrm{f}, \mathrm{B}, \mathrm{C}$ & $6.3 \pm 1.3 \mathrm{~b}, \mathrm{E}, \mathrm{F}$ \\
\hline & 24 & $4.8 \pm 1.0 \mathrm{e}, \mathrm{D}$ & $16.1 \pm 2.8 \mathrm{~g}, \mathrm{D}$ & $7.2 \pm 0.3 \mathrm{~b}, \mathrm{c}, \mathrm{F}$ \\
\hline \multicolumn{5}{|c|}{ Cultivation with biomass after pasteurization } \\
\hline \multirow[t]{3}{*}{$\mathrm{YPD}+1.25 \mathrm{~g}$ of $\mathrm{Mg}^{2+} / \mathrm{L}$} & 0 & $1.4 \pm 0.2 \mathrm{~b}, \mathrm{~A}$ & $3.2 \pm 1.4 \mathrm{~b}, \mathrm{c}, \mathrm{A}$ & $0.9 \pm 0.1 \mathrm{~b}, \mathrm{~A}$ \\
\hline & 6 & $5.8 \pm 0.5 \mathrm{a}, \mathrm{d}, \mathrm{B}$ & $8.2 \pm 1.9 \mathrm{~d}, \mathrm{~B}, \mathrm{C}$ & $5.2 \pm 0.7$ a,c,B,C,D \\
\hline & 24 & $5.4 \pm 1.3 \mathrm{a}, \mathrm{B}, \mathrm{D}$ & $17.8 \pm 5.9 \mathrm{e}, \mathrm{D}$ & $4.9 \pm 0.4 \mathrm{a}, \mathrm{c}, \mathrm{B}, \mathrm{C}$ \\
\hline \multirow[t]{3}{*}{$1.25 \mathrm{~g}$ of $\mathrm{Mg}^{2+} / \mathrm{L}$ solution } & 0 & $1.4 \pm 0.2 \mathrm{~b}, \mathrm{~A}$ & $3.2 \pm 1.4 \mathrm{~b}, \mathrm{~A}$ & $0.9 \pm 0.1 \mathrm{~b}, \mathrm{~A}$ \\
\hline & 6 & $7.2 \pm 1.3 \mathrm{a}, \mathrm{E}$ & $10.4 \pm 3.4 \mathrm{~d}, \mathrm{C}$ & $5.7 \pm 0.3$ a,C,D,E \\
\hline & 24 & $6.1 \pm 0.3 \mathrm{a}, \mathrm{c}, \mathrm{B}$ & $8.9 \pm 3.4 \mathrm{c}, \mathrm{d}, \mathrm{B}, \mathrm{C}$ & $5.8 \pm 0.5 \mathrm{a}, \mathrm{D}, \mathrm{E}$ \\
\hline
\end{tabular}

* Means with the same letters a,b,c... for culture in one type of medium did not differ significantly; means with the same letters A,B,C ... considering one strain of yeasts (column) did not differ significantly (acc. to NIR Fisher's test)

magnesium content in the biomass of yeasts used as an experimental cultivation inoculum was about $0.9 \mathrm{mg}$ of $\mathrm{Mg}^{2+} / \mathrm{g}$ of dry substance of $C$. utilis ATTC 9950 yeast to about $3.2 \mathrm{mg}$ of $\mathrm{Mg}^{2+} / \mathrm{g}$ of dry substance of $S$. cerevisiae No. 1 yeast. Such differences could result from magnesium natural content in the biomass of tested fungi and magnesium ion adsorption from YPD medium. Possibly, YPD medium was a source of $\mathrm{Mg}^{2+}$ cations when generating the inoculum.

After six hours of biosorption, the highest magnesium content was found in S. cerevisiae No. 1 yeast pasteurized biomass following an incubation in YPD medium supplemented with $1.25 \mathrm{~g}$ of $\mathrm{Mg}^{2+} / \mathrm{L}\left(17.8 \mathrm{mg}\right.$ of $\mathrm{Mg}^{2+} / \mathrm{g}$ of yeast dry substance). In $S$. cerevisiae No. 1 and $S$. cerevisiae 102 living cells, incubated for $6 \mathrm{~h}$ in $\mathrm{MgSO}_{4}$ solution, the amount of bound magnesium was 9.5 and $8.0 \mathrm{mg}$ of $\mathrm{Mg}^{2+} / \mathrm{g}$ of yeast dry substance, respectively. It produced a growth by 6.3 and $6.6 \mathrm{mg}$ of $\mathrm{Mg}^{2+} / \mathrm{g}$ of yeast dry substance in comparison with magnesium content in biomass of inoculum of both strains. After carrying out the process for the same length of time, but in YPD $+\mathrm{Mg}^{2+}$ medium, the smallest amount of magnesium was bound by $S$. cerevisiae 102 cells (about $2.8 \mathrm{mg}$ of $\mathrm{Mg}^{2+} / \mathrm{g}$ of yeast dry substance).

In spite of the fact that strains of 102 and No. 1 yeasts belong to the same species ( $S$. cerevisiae), after $24 \mathrm{~h}$ of incubation the differences in magnesium content bound by those fungi were significant. Irrespective of used medium or biomass viability, S. cerevisiae No. 1 was binding 2-3 times more $\mathrm{Mg}^{2+}$ ions from the baker's strain but also from C. utilis fodder yeast. After twenty-four-hour incubation of S. cerevisiae No. 1 living cells in magnesium ion solution, approx. $16 \mathrm{mg}$ of $\mathrm{Mg}^{2+} / \mathrm{g}$ of dry substance was found in that strain biomass, whereas in S. cerevisiae 102 and C. utilis biomass, 4.8 and $7.2 \mathrm{mg}$ of $\mathrm{Mg}^{2+} / \mathrm{g}$ of dry substance, respectively. A comparable degree of binding was achieved only in S. cerevisiae No. 1 and S. cerevisiae 102 living biomass after $24 \mathrm{~h}$ of incubation in YPD mediumcontaining magnesium $\left(2.7\right.$ and $2.4 \mathrm{mg}$ of $\mathrm{Mg}^{2+} / \mathrm{g}$ of dry substance, respectively).

After the experiment, which lasted $24 \mathrm{~h}$, the highest magnesium content was found in $S$. cerevisiae No. 1 pasteurized biomass incubated in YPD $+\mathrm{Mg}^{2+}$ medium (17.8 $\mathrm{mg}$ of $\mathrm{Mg}^{2+} / \mathrm{g}$ of dry substance). The magnesium content after incubation of $S$. cerevisiae No. 1 living cells in $\mathrm{MgSO}_{4}$ solution (16.1 $\mathrm{mg}$ of $\mathrm{Mg}^{2+} / \mathrm{g}$ of dry substance) was comparable. In both cases, an increase in S. cerevisiae No. 1 biomass magnesium content occurred by about $13 \mathrm{mg}$ of $\mathrm{Mg}^{2+} / \mathrm{g}$ of yeast dry substance in comparison with magnesium content in inoculum biomass (2.9-3.2 $\mathrm{mg}$ of $\mathrm{Mg}^{2+} / \mathrm{g}$ of dry substance). The obtained results allowed to state that the $S$. cerevisiae No. 1 strain was characterized by the greatest magnesium biosorption capacity. Gniewosz et al. [12] represented similar data concerning brewer's yeast, but the $S$. uvarum species incubated in magnesium chloride solution $(13.76 \mathrm{mg}$ of $\mathrm{Mg}^{2+} / \mathrm{g}$ of dry substance). 
After twenty-four-hour incubation, the smallest (approx. double) increase in $\mathrm{Mg}^{2+}$ content was observed in baker's yeast living cells of $S$. cerevisiae 102 incubated in YPD $+\mathrm{Mg}^{2+}$ medium. In the inoculum biomass of that strain, about $1.4 \mathrm{mg}$ of $\mathrm{Mg}^{2+} / \mathrm{g}$ dry substance was determined, whereas after incubation of living cells in YPD $+\mathrm{Mg}^{2+}$ medium, about $2.4 \mathrm{mg}$ of $\mathrm{Mg}^{2+} / \mathrm{g}$ of dry substance was present.

The $S$. cerevisiae species is commonly used for manufacturing food products. Its biomass is often a waste from manufacturing processes. Consequently, the biomass can be obtained easily and cheaply in sufficient amounts as a potential biosorbent.

The $C$. utilis yeasts bound the largest amount of magnesium after $24 \mathrm{~h}$ of cultivation in a solution containing magnesium ions (approx. $7.2 \mathrm{mg}$ of $\mathrm{Mg}^{2+} / \mathrm{g}$ of dry substance). It was the greatest increase in magnesium content in a biomass obtained from tested experimental media in that species ( 8 times more magnesium in comparison with magnesium content of $0.9 \mathrm{mg}$ of $\mathrm{Mg}^{2+} / \mathrm{g}$ of dry substance in inoculum biomass). Gniewosz et al. [13] state that after $24 \mathrm{~h}$ magnesium biosorption by $C$. utilis cells lasting in YPD medium supplemented with $\mathrm{MgCl}_{2}$, the biomass contained about $5.2 \mathrm{mg}$ of $\mathrm{Mg}^{2+} / \mathrm{g}$ of dry substance.

With regard to the degree of magnesium binding by S. cerevisiae 102 and C. utilis ATTC 9950 yeast, we may observe that, in most of the experimental media, the biosorption capacity, meaning the amount of magnesium bound by tested yeast biomass, was similar in both species and the ascertained differences were not statistically significant.

After twenty-four-hour incubation of living and dead C. utilis biomass, in YPD medium containing magnesium or magnesium sulfate solution, respectively, a process of biosorbent saturation with magnesium ions was observed. In biomasses incubated as living cells of $C$. utilis in YPD medium supplemented with magnesium ions after six-hour and twenty-four-hour incubation, the magnesium content was 4.3 and $4.4 \mathrm{mg}$ of $\mathrm{Mg}^{2+} / \mathrm{g}$ of dry substance, respectively. The determined contents of magnesium in pasteurized biomass of $C$. utilis after incubation in magnesium solution were 5.7 and $5.8 \mathrm{mg}$ of $\mathrm{Mg}^{2+} / \mathrm{g}$ of dry substance, respectively. The second observed phenomenon was magnesium desorption found in $S$. cerevisiae No. 1 living cell cultivated in YPD $+\mathrm{Mg}^{2+}$ medium. After six-hour incubation, the biomass of $S$. cerevisiae No. 1 contained $7.1 \mathrm{mg}$ of $\mathrm{Mg}^{2+} / \mathrm{g}$ of dry substance, whereas after twenty-four-hour incubation, only $2.7 \mathrm{mg}$ of $\mathrm{Mg}^{2+} / \mathrm{g}$ of dry substance. After twenty-four-hour incubation of $S$. cerevisiae 102 yeasts in magnesium ion solution, the $4.8 \mathrm{mg}$ of $\mathrm{Mg}^{2+} / \mathrm{g}$ of biomass dry substance was determined, significantly less than after six-hour incubation ( $8.0 \mathrm{mg}$ of $\mathrm{Mg}^{2+} / \mathrm{g}$ of dry substance).

Observations have shown that in all yeast cultivations carried out in YPD $+\mathrm{Mg}^{2+}$ medium, the cells of tested strain bound less magnesium than from a $\mathrm{MgSO}_{4}$ solution. Binding of experimental media components to cell wall polymers in those fungi, except magnesium cations, can be a possible cause of that. As a consequence, it conducted to decrease in the number of functional groups that participate in magnesium cation chemisorption.

Biosorption capacity can be increased by yeast cell thermal or chemical treatment, grinding or sonication $[15$, $23,38]$. Disintegration of structures forming the cell wall and cytoplasmatic membrane ensures an easier access of substances incorporated into cell structural components $[8,38]$. Results obtained in the presented paper confirmed that the tested yeast strains cellular biomass pasteurization process had a beneficial effect on magnesium binding from experimental media. Both after incubation of tested yeast strain pasteurized biomass in YPD $+\mathrm{Mg}^{2+}$ medium and $\mathrm{MgSO}_{4}$ solution, the amount of bound magnesium was usually greater than in systems with living cells of tested yeast. After twenty-four hours of incubation the biomass of S. cerevisiae 102 contained about $2.4 \mathrm{mg}$ of $\mathrm{Mg}^{2+} / \mathrm{g}$ of dry substance when the process was carried out in YPD $+\mathrm{Mg}^{2+}$ medium inoculated with living cells and about $5.4 \mathrm{mg}$ of $\mathrm{Mg}^{2+} / \mathrm{g}$ of dry substance when the biosorbent was a thermally inactivated biomass. The $S$. cerevisiae No. 1 living biomass bound approx. $2.7 \mathrm{mg}$ of $\mathrm{Mg}^{2+}$ / $\mathrm{g}$ of dry substance in YPD $+\mathrm{Mg}^{2+}$ medium, whereas a pasteurized one $17.8 \mathrm{mg}$ of $\mathrm{Mg}^{2+} / \mathrm{g}$ of dry substance.

In YPD $+\mathrm{Mg}^{2+}$ media, dependence between tested yeast cell wall thickness (Table 1) and the amount of bound magnesium was not observed. For instance, the C. utilis ATCC 9950 and S. cerevisiae 102, which after twenty-four-hour cultivation in YPD $+\mathrm{Mg}^{2+}$ medium showed a similar cell wall thickness (160 and $170 \mathrm{~nm})$, have bound different amounts of magnesium (about 2.4 and $4.3 \mathrm{mg}$ of $\mathrm{Mg}^{2+} / \mathrm{g}$ of dry substance, respectively). The S. cerevisiae 102 yeast was characterized by a considerably larger mannoprotein layer proportion (38\% of cell wall) than C. utilis (15\%)-Table 1. On the other hand, in $\beta$-glucans fraction of cell wall of tested yeast strains, a reversed dependence was found. The cell wall in $C$. utilis yeasts from YPD $+\mathrm{Mg}^{2+}$ medium had a $\beta$-glucan layer making about $82 \%(144 \mathrm{~nm})$, whereas in $S$. cerevisiae 102, that layer made about $62 \%(111 \mathrm{~nm})$. Klis et al. [21] state that the external mannoprotein layer is less permeable than the glucan layer. Mannoproteins are build of a highdegree glycosylated polypeptides and added sugar chains that can be more or less branched. This determines mannoprotein structural differentiation. Differences can also occur in the protein subunit structure, for example, kind of amino acids that determines cell surface hydrophobicity. In mannosyl side chains of mannoproteins, phosphodiester bonds are also present. That determines a negative charge on the cell surface [21]. Such a state 
affects metal cation binding, whereas chemical composition and structure in those glycoproteins determine accessibility of negatively charged groups. The differentiation of mannoprotein architecture in individual yeast strains could condition the different degree of magnesium ion binding. However, Parvathi et al. [33] state that negatively charged phosphate groups of mannoprotein do not fulfill the most important function in metal cation binding by yeast cell surface. However, the accessibility of hydroxyl, amine and carboxyl groups play key part [4].

In pasteurized biomasses, a cell wall thickness enlargement increased the magnesium binding capacity. Taking into account changes in cell wall thickness in tested yeast strains after pasteurization process and the degree of magnesium biosorption by thermally treated biomass in magnesium ion solution, it was found that the largest amount of cations was bound by $S$. cerevisiae No. 1 ( $8.9 \mathrm{mg}$ of $\mathrm{Mg}^{2+} / \mathrm{g}$ of dry substance) yeast and also had the largest increase in cell wall thickness (Table 1).

It is not possible to indicate one of the cell wall polymers. It would decisively influence magnesium binding in case of all investigated yeasts. Comparing results of magnesium content determination in fungi biomasses after twenty-four-hour incubation in YPD medium and YPD medium supplemented with magnesium, a significant increase in magnesium content was found in C. utilis (increase from $0.9 \mathrm{mg}$ of $\mathrm{Mg}^{2+} / \mathrm{g}$ of dry substance to $4.3 \mathrm{mg}$ of $\mathrm{Mg}^{2+} / \mathrm{g}$ of dry substance) and in $S$. cerevisiae 102 biomass (increase from $1.4 \mathrm{mg}$ of $\mathrm{Mg}^{2+} / \mathrm{g}$ of dry substance to $2.4 \mathrm{mg}$ of $\mathrm{Mg}^{2+} / \mathrm{g}$ of dry substance). Analysis of changes in mannoprotein content in cell wall of $S$. cerevisiae 102 in YPD medium supplemented with magnesium has shown a slight but significant increase in the amount of this polymers in comparison with the YPD medium. This was an increase from 63.2 to $66 \%$ (Table 2). At the same time, there were not observed any significant changes in $\beta$-glucan fractions. We can presume that mannoproteins played an essential part in the magnesium cation binding by S. cerevisiae 102 yeast. In C. utilis cells, incubated in YPD medium that contained magnesium, a significant increase in $\beta$-glucan content occurred (from 68.6 to $78.4 \%$ ) with a concomitant increase in branched, soluble $\beta(1,6)$-glucan content (increase from 42.6 to $53 \%$ ). In the biomass of $S$. cerevisiae No. 1 after $24 \mathrm{~h}$ of incubation, a magnesium content similar to that in cells making the inoculum was determined, whereas after six-hour incubation, those cells bound the largest amount of magnesium (7.1 mg of $\mathrm{Mg}^{2+} / \mathrm{g}$ of dry substance) in comparison with other tested strains. As in C. utilis, in baker's yeast biomasses obtained after $24 \mathrm{~h}$ of incubation in YPD $+\mathrm{Mg}^{2+}$ medium, increased in the $\beta$-glucan content was noticed (from approx. 46-52\%); however, at the same time, the $\beta(1,6)$-glucan proportion in glucose polymer fraction decreased (from approx. 23-17 \%). Perhaps, this was the cause of magnesium cation desorption from that strain biomass after an incubation process lasting for more than $6 \mathrm{~h}$.

Summarizing, incubation of tested yeasts in magnesium ion solution brought about a higher magnesium content in biomasses of all strains in comparison with content of this element in biomasses incubated in YPD $+\mathrm{Mg}^{2}$ media. Pasteurization of yeast cells had a beneficial effect on the magnesium ion binding process, which could result from a cell wall structure loosening caused by high temperature. That rendered magnesium cation binding sites accessiblean increase in cell wall thickness in tested yeast pasteurized biomass indicates this.

\section{Conclusions}

The cell wall structure as well as changes in its chemical composition due to varied conditions of incubation was individual features of tested strains.

The greatest amount of mannoproteins (approx. 63-66 \%) was observed in S. cerevisiae 102 yeast cell wall, whereas $\beta$-glucans in $C$. utilis ATTC 9950 (approx. 69-78 \%). The differences in $\beta(1,3)$ - and $\beta(1,6)$-glucan proportions in cell walls according to species and cultivation conditions were noticed. The S. cerevisiae 102 and $S$. cerevisiae No. 1, yeasts after cultivation in media supplemented with magnesium, contained the largest amount of $\beta(1,3)$-glucans in the total glucose polymer content (approx. 86 and $83 \%$ ). In the same experimental medium in $C$. utilis ATTC 9950 cell walls, a $\beta(1,6)$-glucan content of about $53 \%$ was determined.

Magnesium binding by $S$. cerevisiae No. 1 and $C$. utilis ATTC 9950 yeasts depended on changes in $\beta$-glucan composition and content, whereas in the S. cerevisiae 102 strain, this depended on changes in mannoprotein fraction.

The introduction of an additional source of magnesium into experimental media caused an increase in cell wall thickness. This did not increase magnesium ion binding capacity in living biomass of studied yeast strains. Only in pasteurized biomasses, increased cell wall thickness caused an increase in magnesium binding capacity.

The $S$. cerevisiae No. 1 yeast bound the greatest amount of magnesium accessible in the medium (about 16-18 mg of $\mathrm{Mg}^{2+} / \mathrm{g}$ of dry substance) in comparison with the amount of magnesium adsorbed by $S$. cerevisiae 102 and C. utilis ATTC 9950 biomasses (2.4-8.0 mg of $\mathrm{Mg}^{2+} / \mathrm{g}$ of dry substance).

Living cells of tested fungi bound magnesium from $\mathrm{MgSO}_{4}$ solution more effectively than from YPD medium enriched with magnesium. On the other hand, in YPD $+\mathrm{Mg}^{2+}$ medium, the biosorbent saturation was quicker. This might have 
been caused by binding not only $\mathrm{Mg}^{2+}$ ions but also medium components to the cell wall surface of living yeast.

The $S$. cerevisiae No. 1 yeast strain can be used for the production of $\mathrm{Mg}^{2+}$ increased yeast biomass after $24 \mathrm{~h}$ of incubation of living cells in $\mathrm{MgSO}_{4}$ solution or after pasteurized biomass incubation in YPD $+\mathrm{Mg}^{2+}$ medium.

Open Access This article is distributed under the terms of the Creative Commons Attribution License which permits any use, distribution, and reproduction in any medium, provided the original author(s) and the source are credited.

\section{References}

1. Aguilar-Uscanga B, François JM (2003) Lett Appl Microbiol 37:268-274

2. Błażejak S (2006) Pol J Food Nutr Sci 15(56):9-16

3. Bohn JA, BeMiller JN (1995) Carbohydr Polym 28:3-14

4. Brady D, Duncan JR (1994) Enzym Microb Technol 16(7): 633-638

5. Brady D, Stoll AD, Starke L, Dunkan JR (1994) Biotechnol Bioeng 44(3):297-302

6. Cantu D, Greve LC, Labavitch JM (2009) Powell ALT 113: $1396-1403$

7. Chaffin LW, Lopez-Ribot LJ, Casanova M, Gozalbo D, Martinez PJ (1998) Microbiol Mol Biol Rev 62:130-180

8. Errasquin EL, Vazquez C (2003) Chemosphere 50:137-143

9. Flett GH, Manners DJ (1976) J Gen Microbiol 94:180-192

10. Franco LO, Maia RCC, Porto ALF, Messias AS, Fukushima K, Campos-Takaki GM (2004) Brazilian J Microbiol 35:243-247

11. Ganner A, Stoiber C, Wieder D, Schatzmayr G (2010) J Microbiol Methods 83(2):168-174

12. Gniewosz M, Duszkiewicz-Reinhard W, Błażejak S, Sobiecka J, Zarzecka M (2007) Acta Sci Pol Technol Aliment 6:57-67

13. Gniewosz M, Blażejak S, Roman J, Duszkiewicz-Reinhard W (2006) Eur Food Res Technol 224:49-54

14. Hamza SM, Ahmed HF, Ehab AM, Mohammad FM (2010) J Am Sci 6(12):597-604
15. Han R, Li H, Li Y, Zhang J, Xiao H, Shi J (2006) J Hazard Mater 137:1569-1576

16. Jouany J-P, Yiannikouris A, Bertin G (2005) Archiva Zootechnica 8:26-50

17. Kapteyn JC, Van Den Ende H, Klis FM (1999) Biochimica Biophysica Acta 1426:373-383

18. Kath F, Kulicke W-M (1999) Die Angewande Macromoleculare Chemie 268:59-68

19. Kim KS, Yun HS (2006) Enzym Microb Technol 39:496-500

20. Klis FM, Boorsma A, De Groot PWJ (2006) Yeast 23:185-202

21. Klis MF, Mol P, Hellingwerf K, Brul S (2002) FEMS Microbiol Rev 26:239-256

22. Kogan G, Kocher A (2007) Livestock Sci 109:161-165

23. Kordialik-Bogacka E (2011) Cent Eur J Chem 9(2):348-351

24. Latgó J-P (2007) Mol Microb 66(2):279-290

25. Latgó J-P (2010) Cell Microb 12(7):863-872

26. Lipke PN, Ovalle RJ (1998) Bacteriology 180:3735-3740

27. Liu X-Y, Wang Q, Cui SW, Liu H-Z (2008) Food Hydrocoll 22:239-247

28. Lu Y, Wilkins E (1996) J Hazard Mater 49:165-179

29. Lucca ME, Romero ME, Callieri DAS (1995) J Microbiolol Biotechnol 11:515-518

30. Magnelli P, Cipollo JF, Abeijon C (2002) Anal Biochem 301:136-150

31. Nguyen TH, Fleet GH, Rogers PL (1998) Appl Microbiol Biotechnol 50:206-212

32. Orłowski J, Machula K, Janik A, Zdebska E, Palamarczyk G (2007) Yeast 24:239-252

33. Parvathi K, Nagendran R, Nareshkumar R (2007) Electron J Biotechnol 10(1):1-14

34. Ruiz-Herrera J, Mormeneo S, Vanaclocha P, Font-de-Mora J, Iranzo M, Puertes I, Sentadreu R (1994) Microbiology 140:1513-1523

35. Smits GJ, Kapteyn JC, van den Ende H, Klis FM (1999) Curr Opin Microbiol 2:348-352

36. Suphantharika M, Khunrae P, Thanardkit P, Verduyn C (2003) Bioresour Technol 88:55-60

37. Thanardkit P, Khunrae P, Suphantharika M, Verduyn C (2002) World J Microbiol Biotechnol 18:527-539

38. Wang JL, Chen C (2009) Biotechnol Adv 27:195-226 